NBER WORKING PAPER SERIES

HAVE U.S. CORPORATIONS GROWN

FINANCIALLY WEAK?

Robert A. Taggart, Jr.

Working Paper No. 1523

NATIONAL BUREAU OF ECONOMIC RESEARCH

1050 Massachusetts Avenue

Cambridge, MA 02138

December 1984

The research reported here is part of the NBER's research program in Financial Markets and Monetary Economics. This paper was presented at a conference held in Williamsburg, Virginia, on September $20-21,1984$, as part of the NBER's project on Corporate Capital Structures in the United States which is sponsored by the American Council of Iife Insurance. Any opinions expressed are those of the author and not necessarily those of the NBER or the ACLI. 
NBER Working Paper \#1523

December 1984

\section{Have U.S. Corporations Grown \\ Financially Weak?}

\section{$\underline{\text { ABSTRACT }}$}

The feeling is widespread that the financial strength of U.S. corporations has eroded over the past twenty years. This trend is often blamed on some combination of the tax system, inflation and overly optimistic assessments of business risk.

This paper examines recent corporate financing developments from a long-run perspective. It is concluded that these developments appear less dangerous when viewed in the context of the twentieth century as a whole than when viewed in the context of the post-World war II years. A second major conciusion is that powerful corrective mechanisms are at work to keep corporate financial positions from becoming too risky. These forces have been particularly noticeable over the past ten years. Third, the effects on business financing of the tax system, inflation and business risk are difficult to trace in the aggregate data, and these effects may be less straightforward than has commonly been thought. Finally, it is argued that the degree of economic instability and the relative level of federal government borrowing will be key determinants of future corporate financing patterns.

Robert A. Taggart, Jr. Boston University School of Management 704 Commonwealth Avenue Boston, MA 02215 
HAVE U.S. CORPORATIONS GROWN FINANCIALLY WEAK?

The feeling is widespread that the financial streng,th of U.S. corporations has eroded over the past twenty years. ${ }^{1}$ The apparent increase in debt financing, especially short-term and floating rate debt, has alarmed many observers. Declining liquidity ratios and heavy reliance on external funds have also caused concern. These trends are typically blamed on some combination of three factors: the tax system, which is said to favor debt over equity financing; inflation, which causes internal funds to lag behind total needs and which is alleged to make debt cheap; and overly optimistic assessments of business risk.

This paper examines corporate financing developments of the past two decades from a long-run perspective. Recent years' trends are compared with those for the twentieth century as a whole in an attempt to shed some light on the following questions: Is it true that corporations have increasingly relied on external funds of all kinds, especially debt? Are the trends of recent years unusual in light of prior years? What causes long-run patterns in corporate finance? Have U.S. corporations indeed become financially weak?

Section I of the paper uses a variety of data sources to determine what financing trends have actually occurred over the twentieth century. Special emphasis is placed on the problem of accurate measurement during inflationary periods. Section II examines the ability of taxes, inflation and perceived business risk to explain these financing trends. The impact of federal government borrowing on the financing decisions of the business sector is also considered. Section III summarizes the paper's findings and attempts to identify the key determinants of future developments in corporate financing. 
I. Corporate Financing Trends, 1900-1983

A. Debt Ratios

Perhaps the most commonly-used measure of financial condition is some form of debt ratio, computed with ordinary accounting data. For the U.S. corporate sector as a whole, such data are available from the Internal Revenue Service Statistics of Income for the years 1926-81 and from this data the ratio of long-term debt to total capitalization is graphed in

(FIG. 1 HERE)
Figure 1. It is easy to see from this figure why there is a widespread feeling not only that corporate debt usage has increased steadily in the years since World War II but that it has reached historical peaks in recent years. ${ }^{2}$ Perhaps less widely appreciated is the apparent fact that the rise in debt ratios ceased in the early 1970s. One might conclude from Figure 1 that U.S. corporations were increasingly willing to take on financial risk in the postwar years but that debt ratios have remained stable at a new higher plateau for roughly the past decade.

However, the accounting data on which Figure 1 is based are subject to several potential biases and should be interpreted with caution. Liberalization of depreciation allowances, as has occurred at several points from the 1960 s onward, increases corporate cash flow but reduces measured profits and retained earnings. Thus debt ratios will tend to be overstated when allowed depreciation is increased. Inflation also causes distortions in accounting data. Reported asset values may be understated in an inflation, resulting in overstated debt ratios. Likewise, standard accounting data do not reflect decreases in the real value of debt and reported debt ratios may thus exaggerate the real burden of corporate liabilities. On the other hand, accounting data have not traditionally 
FRACTION OF

TOTAL CAPITALIZATION

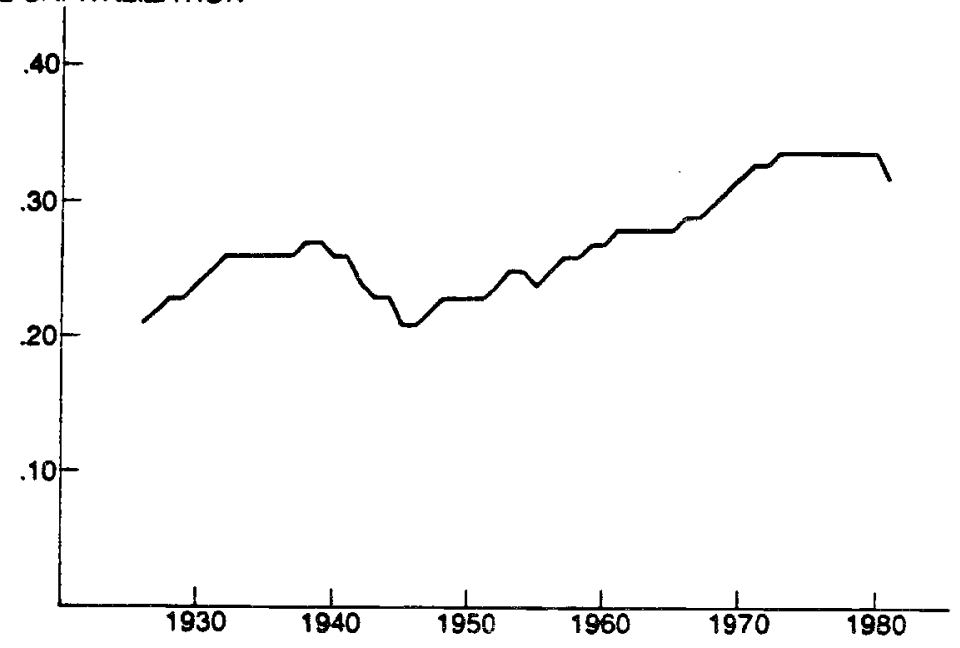

Figure 1

Ratio of Long-Term Debt to Total

Capitalization, All U. S. Corporations 
included such off-balance sheet items as lease obligations and unfunded pension liabilities, so reported debt ratios may also contain some understatements. 3

(FIG. 2 HERE)

Figure 2 tracks the movement of two alternative debt ratio calculations that attempt to correct for some of the biases in standard accounting data. The first of these is an estimated ratio of the market value of debt to the market value of total capitalization of U.S. nonfinancial corporations. The underlying data are taken from Holland and Myers (1979), who estimated market values for debt and equity by capitalizing total corporate interest and dividend payments at current market yields. The market value ratio should adjust for inflation-induced valuation changes and thus provide a more accurate measure of the burden of corporate debt. The primary disadvantages of this measure are that it is subject to estimation error, and it does not allow separation of actual corporate financing decisions from changes in market valuation.

As shown in Figure 2, the market value debt ratio is more volatile than the book value ratio. It does, however, exhibit somewhat the same general pattern. Corporate debt ratios were relatively high in the $1930 \mathrm{~s}$ and early 1940 s but they declined markediy by the end of World War II. There then appears to have been an upward trend in the postwar period, although the market value data suggest that much of the upward movement took place in the late 1960s and early 1970s. Finally, this rise in the debt ratio leveled off in the mid-1970s, with declines occurring in the most recent years.

The second ratio graphed in Figure 2 is an estimated ratio of the market value of debt to the replacement value of assets for U.S. nonfinancial 


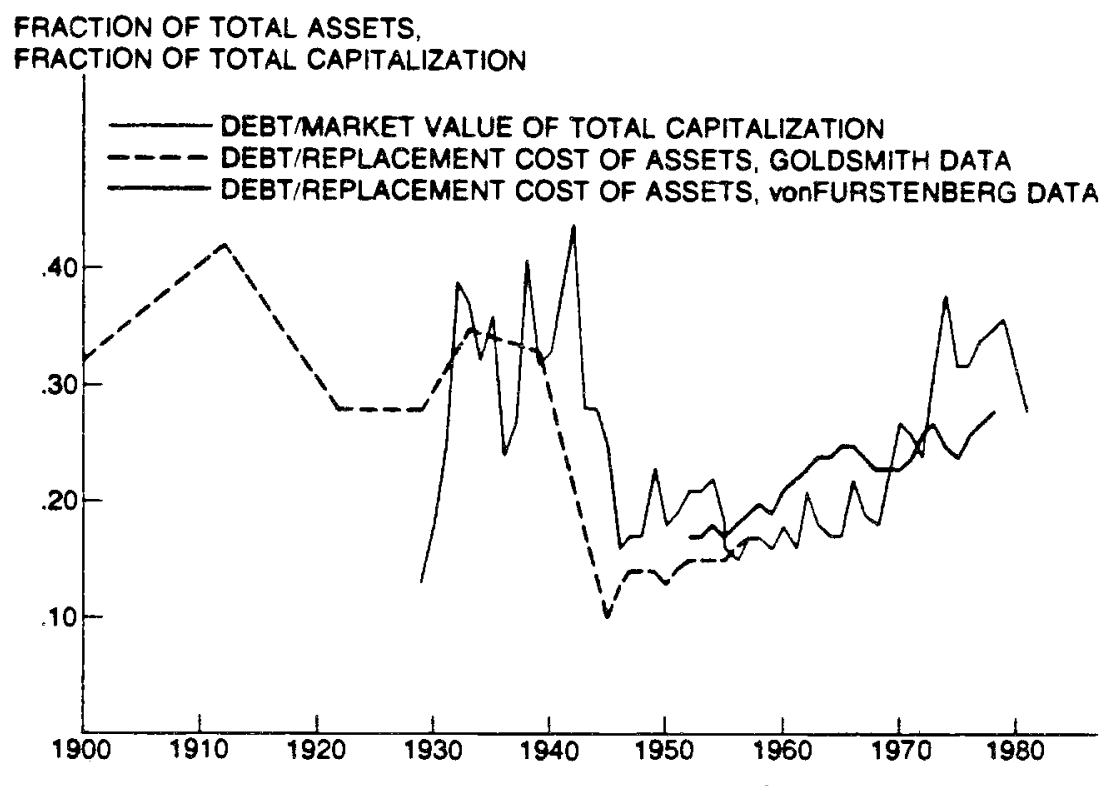

Figure 2

Market Value and Replacement Value Debt Ratios, U. S. Nonfinancial Corporations 
corporations. Like the market value data, the replacement value estimates are aimed at eliminating inflationary distortions. Another advantage of this measure is that by combining Goldsmith et al.'s (1963) estimates for the early years with more recent estimates by von Furstenberg (1977), it is possible to put together a long series of comparable ratios.

Again, the replacement value ratios exhibit a broad pattern that is similar in many respects to that of the book value ratios: corporate debt usage apparently fell to a low point at the end of World War II and subsequently rose. However, the replacement value data suggest that the steadiest increases were over by the mid-1960s, with a more cyclical pattern ensuing since then. An especially interesting feature of the replacement value data is their implication that corporate debt usage was quite high early in the century. By these estimates, the corporate debt ratio was unusually low at the end of World War II, and it has only recently attained the levels that were normal in the period 1900-1930.

Considered as a group, all three debt ratio measures suggest that the end of World war II may be a quite misleading reference point from which to judge recent corporate financing trends. It seems undeniable that corporate debt usage has risen in the postwar period, but it is far from clear that current debt levels are unusually high when viewed from a longrun perspective.

B. Liquidity Ratios

Liquidity ratios are a second type of balance sheet ratio frequently used to measure financial condition. The ratios of liquid assets to total assets and to short-term liabilities for U.S. nonfinancial corporations HERE) are shown in Table 1 for selected years. Total assets are measured at 
Table 1

Liquid Asset Ratios

U.S. Nonfinancial Corporations

$\begin{array}{lcc}\text { Year } & \text { Liquid Assets }^{\text {Total Assets }} & \text { Liquid Assets }^{2} \\ 1900 & .061 & .299 \\ 1912 & .066 & .322 \\ 1922 & .070 & .300 \\ 1929 & .067 & .311 \\ 1933 & .060 & .297 \\ 1939 & .076 & .452 \\ 1945 & .167 & .822 \\ 1953 & .121 & .597 \\ 1964 & .086 & .373 \\ 1975 & .056 & .301 \\ 1982 & \text { N.A. A. } & .248\end{array}$

${ }^{1}$ Liquid assets consist of currency, deposits and marketable securities other than corporate stock. Total assets are measured at replacement value. Data for 1900-1945 are from Goldsmith et al. (1963) and for 1953-1975 from Goldsmith (1982).

2 Short-term liabilities are loans (except mortgages), short-term paper, profit taxes payable and trade debt. Data for 1900-1945 are from Goldsmith et al. (1963) and for 1953-1982 from Board of Governors of the Federal Reserve System, Flow of Funds Accounts. 
replacement value, while short-term liabilities are measured at book value. As worried observers have noted, there indeed appears to have been a substantial decline in corporate liquidity during the postwar period. However, as with the debt ratios, 1945 was a year of unusually low financial risk for corporations. Not only were their debt ratios at historic lows by the end of the war, but they held large amounts of U.S. government securities as well. If we subtracted liquid asset holdings from total debt, we would see that corporations were effectively in a position of negative leverage at that time.

From a Ionger-run perspective, recent ratios of liquid assets to total assets do not seem alarmingly low. Their levels are roughly commensurate with those of the 1900-1930 period. It does appear, though, that the most recent ratio of liquid assets to short-term liabilities is somewhat low, even by historical standards. This suggests that short-term debt has risen in relative terms at the same time that liquid assets have been declining. Whether or not this trend is cause for concern will be considered further below.

\section{Flows of Funds}

A different approach to assessing corporations' financial condition is to examine flows of $\mathrm{funds}$ over selected periods. While the balance sheet measures the cumulative effect of all prior flows as of a particular moment, the flow data reflect corporations' actual financing decisions during specified periods. In Figure 3, for example, the yearly flows of gross internal funds (retained earnings plus depreciation allowances), total debt and new equity issues, expressed as fractions of total yearly 


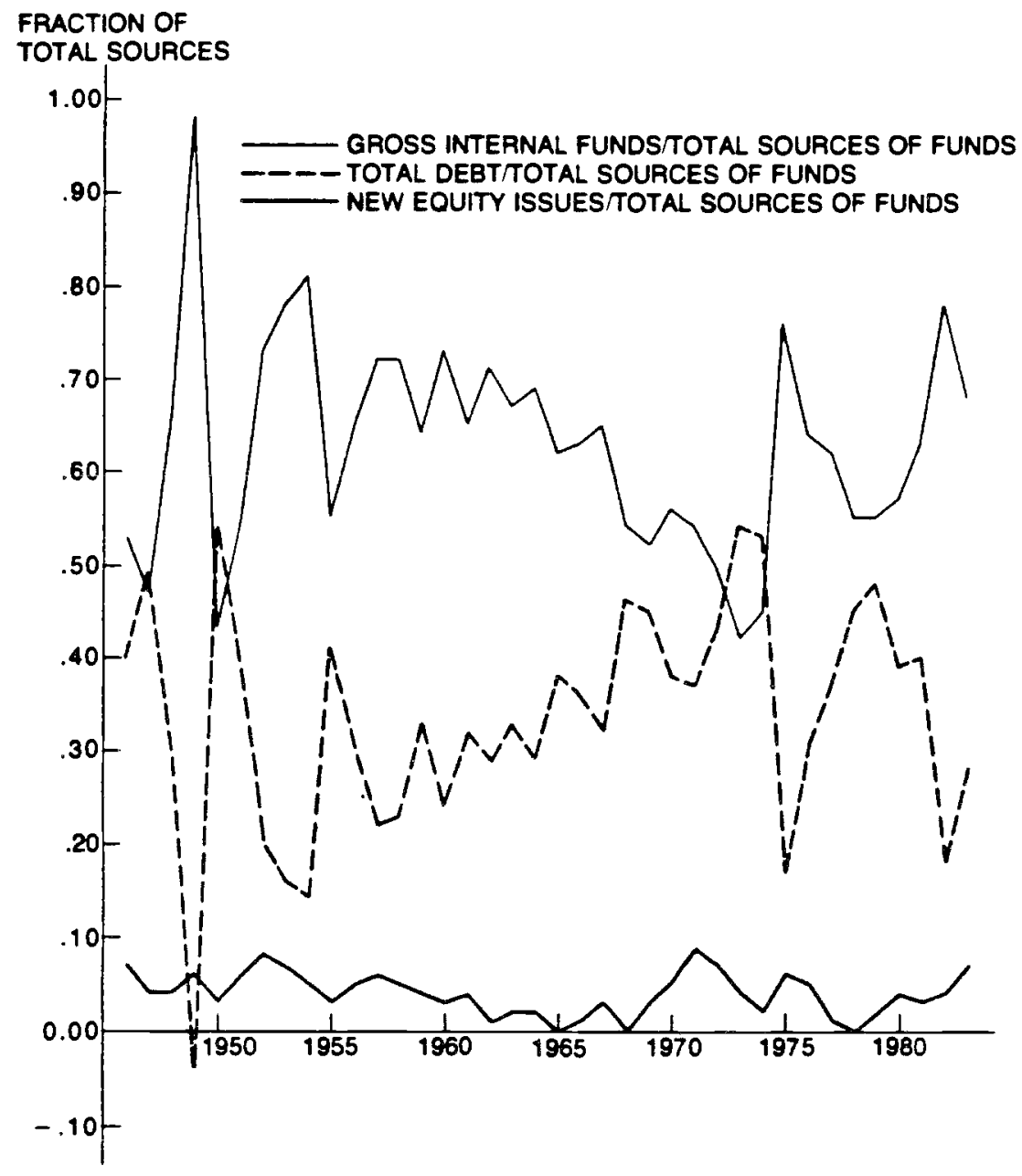

Figure 3

Composition of Funds Sources,

U. S. Nonfinancial Corporations 
sources of funds for U.S. nonfinancial corporations, are graphed for the period 1946-1983. Data are taken from the Federal Reserve's Flow of Funds Accounts.

These data do give one indication of financial duress for the corporate sector in recent years that was not readily apparent in the balance sheet data: the volatility of funds flow composition has increased tremendously since the early 1970s. The availability of internal funds relative to total financing needs has alternately plunged and soared. Simultaneously, debt usage has reached unusually high levels when internal funds were short and unusually low levels when internal funds were plentiful. Once again it should be noted, though, that one's reference point is important to any conclusions about volatility. It could possibly be argued that the period from the late 1950 s to the late ' 60 s was one of unusual stability and that recent fluctuations are more akin to those experienced in the immediate postwar years.

An accurate picture of long-term trends is more likely to emerge if

(TABLE 2 HERE) we smooth out some of these yearly fluctuations. The same funds flow ratios are thus shown for five-year periods in Table 2. The use of Ionger periods also allows the Flow of Funds data to be supplemented by Goldsmith's (1958) estimates of funds flow composition for selected periods between 1900 and 1945.

Several trends are apparent in Table 2. First, debt has accounted for a consistently larger fraction of total financing since the mid-1960s than was the case for nearly all prior periods. Even with recent declines from the 1969-73 peak, debt financing appears to be quite high. Second, the rise in debt financing has not been caused by an increase in long-term 
Table 2

Composition of Financing Flows

U.S. Nonfinancial Corporations

Fractions of Total Sources of Funds ${ }^{1}$
(1)
(2)
(3)
(4)

(5)

$\begin{array}{lc}\text { Total } & \text { Long-Term } \\ \text { Debt } & \text { Debt }\end{array}$

Period

1901-12

1913-22

1923-29

1930-39

1940-45

1946-48

1949-53

$1954-58$

$1959-63$

1964-68

1969-73

$1974-78$

1979-83
Total Short-Term Liabilities

.23

.12

.22

$-.05$

$-.05$

.18

.14

.15

.14

.15

.19

.13

.09
.08

.17

.04

$-.29$

.20

.22

.16

.13

.16

.22

.26

.25

.26
Short-Term New Stock Credit Market Issues Debt ${ }^{3}$

$\begin{array}{lll} & .14 & .55 \\ & .11 & .60 \\ & .19 & .55 \\ & .19 & 1.14 \\ .09 & .05 & .80 \\ .04 & .04 & .56 \\ .05 & .06 & .64 \\ .06 & .05 & .68 \\ .10 & .02 & .68 \\ .11 & .01 & .62 \\ .12 & .06 & .50 \\ .14 & .02 & .60 \\ & .02 & .63\end{array}$

${ }^{1}$ Columns may not add to totals because of rounding.

${ }^{2}$ Long-term debt is defined as bonds and mortgages. All bank loans are included as shortterm debt even though some fraction of these have maturities longer than one year. ${ }^{3}$ Includes bank loans, commercial paper, acceptances, finance company loans and U.S. government loans.

Sources: Goldsmith (1958) and Board of Governors of the Federal Reserve System, Flow of Funds Accounts 
debt, which, if anything, may exhibit some downtrend. Rather, it is shortterm liabilities that have increased markedly. Third, the increase in short-term debt cannot be predominantly attributed to the growth of such spontaneous liabilities as tax accruals and trade debt. Much of it has come from credit market instruments, such as bank loans and commercial paper. 4 Fourth, stock issues fell precipitously as a source of funds during World War II and have remained low ever since. Finally, it is difficult to discern any long-run trend in internal funds.

At least in part, then, any trend toward increased debt-equity ratios could be characterized as a substitution of short-term debt for external equity. Such a characterization offers some support for the fears of those observers who argue that U.S. corporations have dramatically increased their exposure to financial risk.

However, this interpretation of the data is subject to qualification. As it does with the balance sheet ratios, inflation may distort the financing picture reflected in the Flow of Funds data. In particular, von Furstenberg and Malkiel (1977) have argued that annual funds flows should be adjusted for any changes in firms' real indebtedness during the year that are caused by changes in the price level.

Suppose, for example, that the real interest rate is 4 percent. If expected inflation suddenly increases from zero to 8 percent, lenders will demand a nominal interest rate of roughly 12 percent in order to provide themselves a 4 percent real return. If the inflationary process is neutral, one would expect these nominal adjustments to take place, leaving the real pattern of corporate profits, investment and financing undisturbed. 
Note, however, that in this example a neutral inflation will increase corporations' operating cash flows by 8 percent, while their nominal interest payments rise by 200 percent. As conventionally reported, corporate internal funds will not rise as fast as the inflation rate. If the flow of debt financing remains constant in real terms, this necessarily implies that nominal debt financing will rise relative to nominal internal funds.

The inflation premium in nominal interest payments is more appropriately treated as a return of the lender's real principal, which just compensates for the decline in real value of the nominal principal. As a return of principal, however, this amount should not be deducted from corporate profits but rather treated as any other net retirement of debt. By this argument, we should therefore add to reported internal funds any decline in the real value of outstanding debt, since it is not in the true sense a current expense. The same amount should also be subtracted from reported debt issues. Since it represents a retirement of real principal, only new debt issues over and above this amount represent net increases in real debt.

The data in Table 2 were therefore adjusted for changes in real indebtedness, following the procedure outlined in von Furstenberg and Malkiel (1977). The revised relative proportions of gross internal funds and total debt are shown in Table 3, alongside the corresponding unadjusted figures.

The adjusted figures give the impression that recent debt proportions are by no means unusually high. Even after adjusting for inflation, however, the proportions of debt financing in the late 1960 s and early 1970 s were unusually high and the past eight years have witnessed a substantial correction. Much of this correction has occurred through heavy reliance on adjusted internal sources. Instead of financing funds needs with increasing, 
Table 3

Composition of Corporate Financing, Flows

Adjusted for Changes in Real Indebtedness

Fractions of Total Sources

\begin{tabular}{cccc}
\hline \multicolumn{2}{c}{$\begin{array}{c}\text { Gross Internal } \\
\text { Funds }\end{array}$} & \multicolumn{2}{c}{ Total Debt } \\
\hline $\begin{array}{c}\text { (1) } \\
\text { Unadjusted }^{1}\end{array}$ & Adjusted & & $(4)$ \\
.55 & .56 & Unadjusted & Adjusted \\
.60 & .67 & .31 & .30 \\
.55 & .55 & .29 & .22 \\
1.14 & 1.23 & .26 & .26 \\
.80 & .87 & -.33 & -.39 \\
.56 & .64 & .15 & .08 \\
.64 & .67 & .40 & .32 \\
.68 & .71 & .30 & .27 \\
.68 & .69 & .28 & .24 \\
.62 & .65 & .30 & .29 \\
.50 & .56 & .37 & .34 \\
.60 & .71 & .45 & .39 \\
.63 & .75 & .38 & .27 \\
& & .35 & .23
\end{tabular}

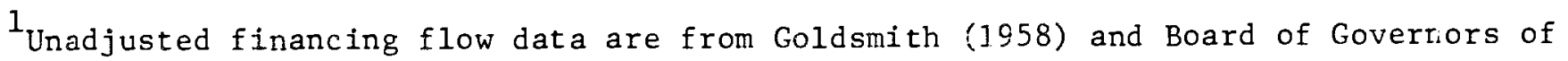
the Federal Reserve System, Flow of Funds Accounts

${ }^{2}$ Data are adjusted by subtracting the change in real indebtedness for the period from gross internal funds and adding the same change to total debt. Changes in price level are measured by the implicit GNP deflator for 1901-48 (source: Historical Statistics of the United States) and by the index of total cost and profit for nonfinancial corporations for 1949-83 (source: Economic Report of the President). Data on total liabilities outstanding at the beginning of each period are from Goldsmith et al. (1963) and Board of Governors of the Federal Reserve System, Flow of Funds Accounts. 
or even constant proportions of real debt, corporations have in effect been retiring some of their maturing real debt principal with internal funds. D. Dividend Payout Ratios

The assertion that corporations have placed heavy emphasis on internal funds in recent years naturally raises the question of whether they have sacrificed dividend payments in order to do so. Three measures of corporate

(TABLE 4 HERE)

dividend payout over selected periods are presented in Table 4.

The ratios in columns 1 and 2 measure dividend payments relative to total available internal funds. Both the adjusted and unadjusted internal funds measures from Table 3 have been used in computing these ratios. The data suggest that corporations did indeed cut their dividend payout somewhat, even before the peak in debt issuance, in an attempt to increase the share of equity financing.

The more traditional measure of payout, dividends divided by net profit after taxes, is shown in Column 3. These figures also convey the impression that dividends were cut fairly severely in order to conserve internal funds, beginning as early as the mid-1960s. Some of the decline in payout in the mid-1960s may be attributable to the well-known tendency of dividends to lag behind profits. However, subsequent periods were not particuarly profitable ones for U.S. corporations, so this does not explain away the long period of relatively low payouts from 1964 to the present. The decline in payout during the $1974-78$ period is particularly dramatic.

\section{E. Summary of Financing Trends}

Does the weight of the evidence support the view that U.S. corporations have become increasingly prone to financial weakness? In most respects, I believe the most plausible answer is no. Many assertions of corporate balance sheet deterioration use the end of World War II as their reference 
Table 4

Dividend Payout Ratios

\section{Dividends Dividends plus Gross Internal Funds U.S, Nonfinancial Corporations} (1) Unadjusted
(2) Adjusted
Dividends Net Profit After Tax

A11 U.S. Corporations

(3)

$$
.64
$$

.74

1.40

1.30

.65

.46

.53

.60

.67

.50

.54

.39

.55

Sources: Board of Governors of the Federal Reserve System, Flow of Funds Accounts and U.S. Internal Revenue Service, Statistics of Income 
point, but as we have seen, that was hardly a typical time. Viewed from a longer-run perspective, current corporate debt usage does not appear dangerously high nor does liquidity appear dangerously low. ${ }^{5}$ In addition, adjustment for inflationary distortions over the past fifteen years removes some of the trend toward increased debt that appears in the raw data. Finally, it should be recognized that corporations have made substantial efforts over the past eight years, particularly through reduced dividend payout, to rebuild financial strength.

Nevertheless, some opposing points must be conceded. The financial environment of the past ten to fifteen years has been more volatile, as is reflected in the sharp changes in the composition of funds sources. Corporate treasurers have had to act more nimbly and imaginatively in order to keep up with the fluctuations in external funds needs. Increased use of short-term and floating rate debt has undeniably made corporations more vulnerable to interest rate fluctuations. And even if some of corporate borrowing in recent years is a rolling over of real principal instead of net new debt, it is still true that these rollovers necessitate more frequent visits to the capital market.

II. What Causes the Trends in Corporate Financing?

Regardless of our perception of financial strength or weakness, we could feel more comfortable with our understanding of these corporate financing developments if we knew their primary determinants. This in turn necessitates a theory of corporate capital structure.

It is widely believed that corporations adjust their financing to some target balance sheet composition. As Myers (1984) has argued, 
the adjustment process may be quite slow, and thus there may be a good deal of slippage between actual and target balance sheets. For example, subject to their established dividend policies, firms may have a decided preference for internal over external funds, and, to the extent that external funds are needed, for debt over stock issues. Thus when internal funds are plentiful relative to investment needs, debt ratios will fall below target, while the reverse will occur when internal funds are in short supply.

Despite this slippage, the influence of the target financing composition will be felt over the long run. Corporations do reach points where they feel their debt capacity is exhausted and they must turn to external equity. Moreover, the standards for debt capacity and the willingness to issue equity appear to change over time. From Table 2, the reluctance to issue equity was apparently much less in the 1900-1940 period than it has been in recent decades.

The primary determinants of these changing standards that have been emphasized by business financing observers are perceptions of business risk, the level of corporate and personal taxes and inflation. In the paragraphs that follow we will explore the extent to which changes in these underlying factors correspond to business financing patterns. The possible influence of federal government borrowing on business financing will also be considered.

\section{A. Business Risk}

Since the threat of bankruptcy entails both explicit and implicit costs, firms will limit their debt ratios in order to avoid it. For any given debt level, the threat of bankruptcy is greater as the degree of 
business risk increases. Thus we would expect an inverse relationship between corporate debt ratios and perceived business risk.

Unfortunately, perceived business risk is notoriously dificult to measure. A possible proxy for investors' risk perceptions in a given year is the standard deviation of monthly percentage stock price changes for that year. Estimates of these standard deviations, derived from Standard

(FIG. 4 HERE) and Poor's Composite Index for the years 1900- 1980 are shown in Figure 4, plotted against the pattern of replacement value debt ratios.

Movements in stock price volatility are dominated by the tremendous fluctuations of the Depression era. Figure 4 thus offers some support for the argument made by many observers: Corporate debt ratios plunged in the wake of the huge increases in business risk during the Great Depression and then began a long and steady climb, as business risk consistently remained at lower levels in the postwar years.

However, the ability of this proxy for business risk to explain the shorter swings in corporate debt ratios is not very great. One might argue that the increased volatility around 1980 is associated with the reductions in debt financing that are apparent in the Flow of Funds data in Tables 2 and $3 .{ }^{6}$ But the sharp changes in the debt ratio between 1900 and 1922 do not correspond to changes in volatility, and it is similarly difficult to match up most financing swings since 1960 with stock price fluctuations. Overall, the evidence that perceived business risk continually and consistently affects corporate financing patterns is limited.

\section{B. Corporate and Personal Taxes}

It is commonly held that the tax deductibility of interest favors debt over equity financing. From an investor's standpoint, however, interest is taxable at ordinary income rates, whereas a substantial 


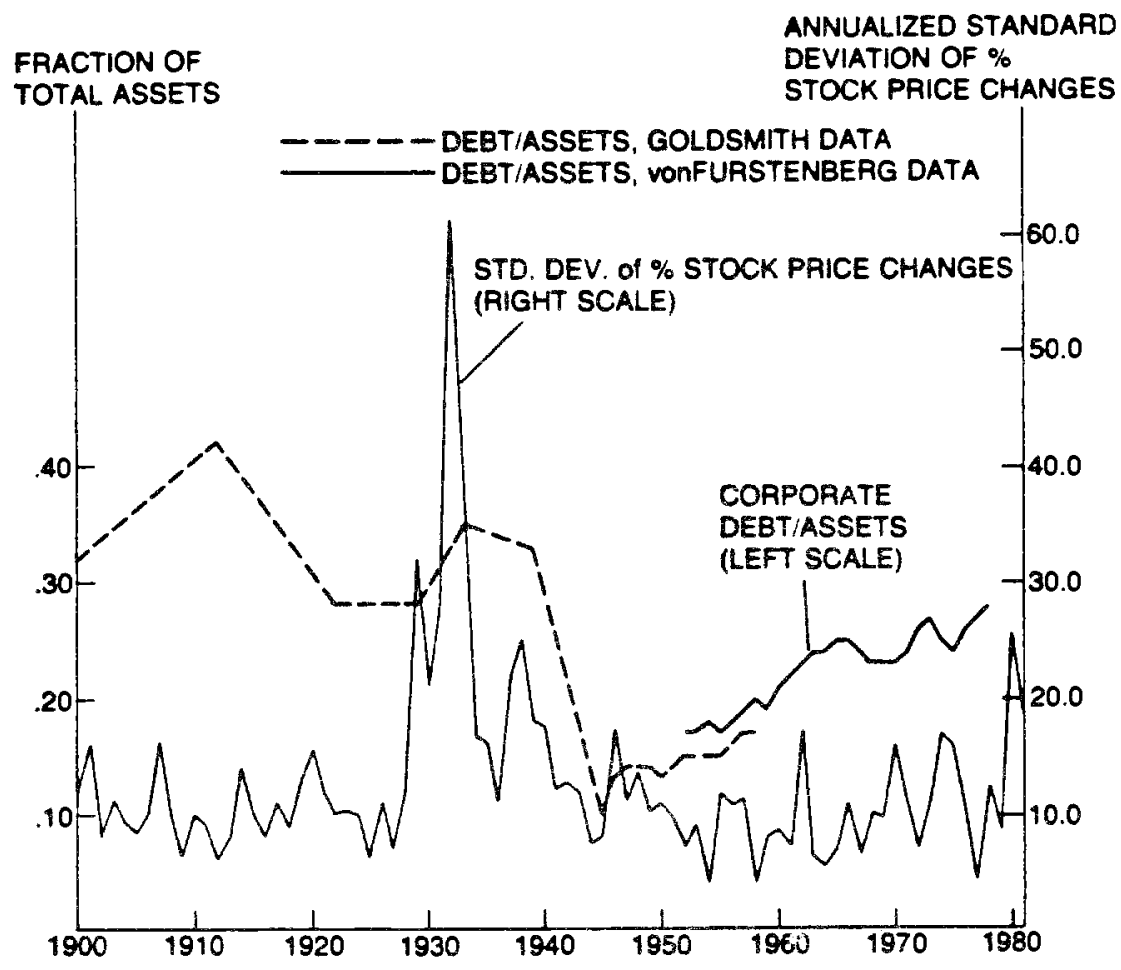

Figure 4

Corporate Debt Ratios and Perceived

Business Risk 
fraction of the returns to equity are taxed at lower capital gains rates. The degree to which the tax advantage of debt at the corporate level outweighs its disadvantage at the investor level thus depends on the relative magnitudes of corporate and personal tax rates.

There is, of course, a whole spectrum of personal tax rates, and what is really needed is some idea of the distribution of investor wealth across tax brackets. In the absence of such information, a cruder measure, which I label the "debt incentive tax ratio" has been constructed as a proxy for the net tax advantage of corporate debt. It is essentially a comparison between statutory corporate tax rates and the lowest level of statutory personal rates. ${ }^{7}$ This debt incentive tax ratio

(FIG. 5 HERE) has been graphed in Figure 5 against the replacement value debt ratio.

Figure 5 indicates that the biggest increase in the net tax advantage to corporate debt occurred between the 1ate 1930 s and early 1950 s. The fact that this tax advantage has remained at a relatively high level for the past forty years is undoubtedly related to the postwar increases in corporate debt. This tax advantage has been nearly constant for some time, though, so it cannot explain short-run fluctuations in the debt-equity mix. It is also something of a puzzle that debt financing proportions were high early in the century when there was no tax advantage and then fell after the tax code was introduced.

While there is little evidence of a close correspondence between movements in tax rates and corporate debt ratios, it is possible that some of the effect of tax considerations has been felt in more subtle ways. One could argue on the basis of Table 4 that corporations have cut their dividend payouts somewhat in the wake of personal tax increases occurring in the 1940s 


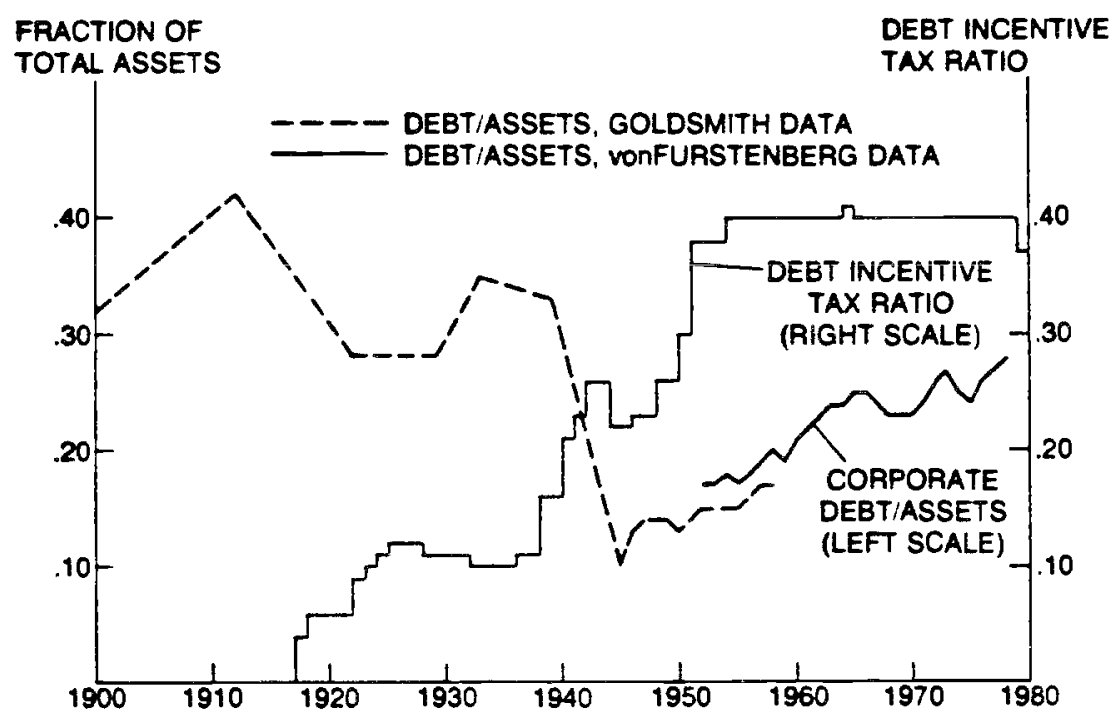

Figure 5

Corporate Debt Ratios and

Income Tax Rates 
and have thus substituted internal for external equity. In addition, tax considerations have clearly influenced the design of securities, apart from their relative proportions. This can be seen through such recent innovations as original-issue discount bonds, adjustable rate preferred stock and the short-lived adjustable rate convertible note. C. Inflation

Inflation is a third factor that is often thought to affect corporate financing proportions. One argument is that inflation enables corporations to repay their debt with cheaper dollars, but it is hard to understand why investors would not try to protect themselves through higher interest rates. A more sophisticated argument revolves around the fact that as it causes interest rates to rise, inflation increases the effective real tax deductions associated with debt. The inflation premium in interest rates is, of course, also taxable to investors, but as long as the corporate tax rate exceeds the personal rate of the marginal bondholder, inflation may cause the net tax advantage of corporate debt to increase.

(FIG. 6 HERE)

In Figure 6, annual inflation rates, as measured by percentage changes in the GNP deflator, are graphed against replacement value debt ratios. Although debt ratios have been relatively bigh in the inflationary years of the 1970s, it would be difficult to argue on the basis of Figure 6 that there has been a close positive relationship between the movements in inflation rates and debt ratios.

Again, as with tax considerations, some of inflation's effects may manifest themselves in more subtle ways. To see one such effect, consider the role of corporations in the financial system: Corporations perform an intermediary role, purchasing and managing productive assets and, in effect, repackaging these assets for investors in the form of debt and equity claims. 


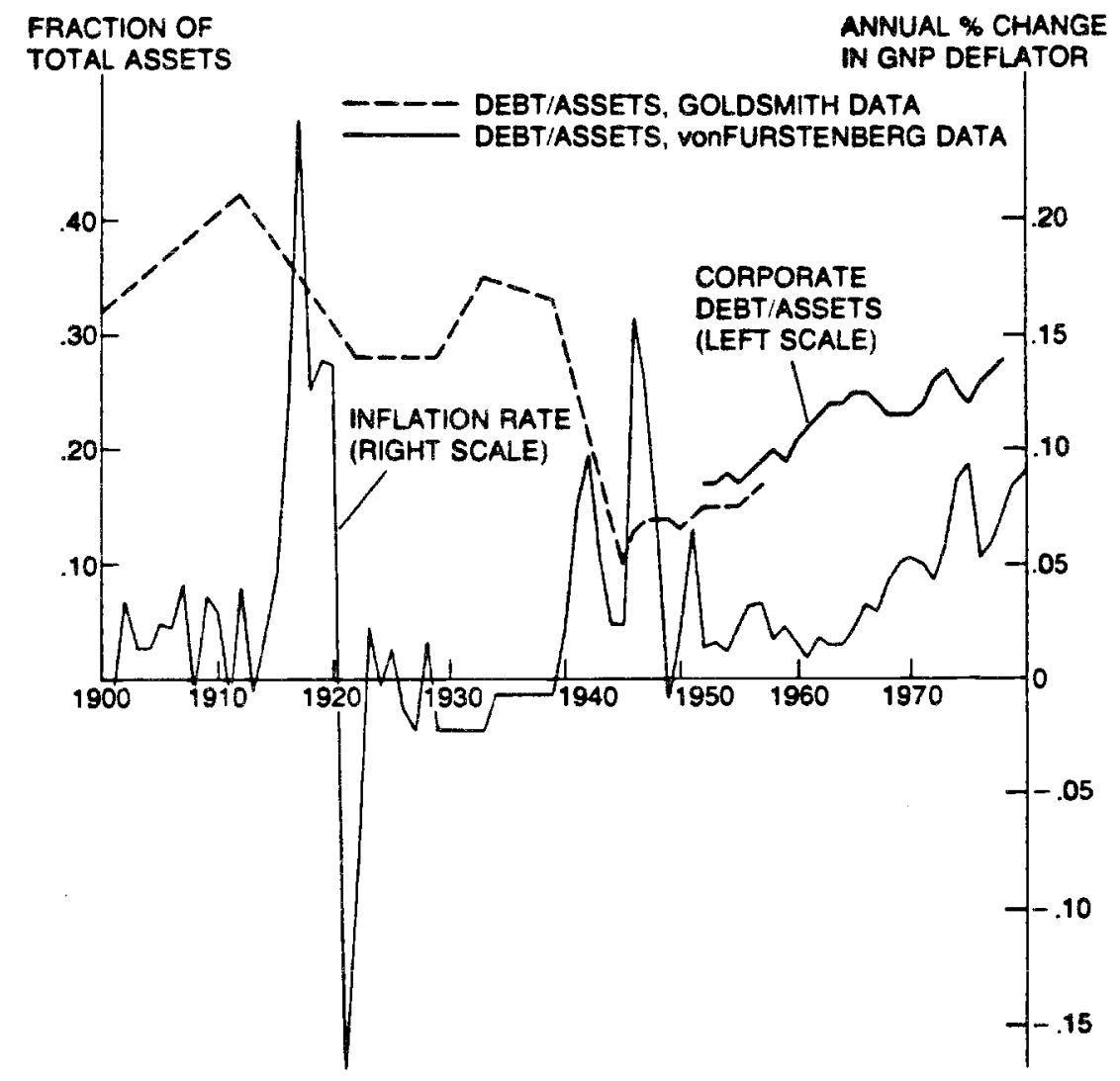

Figure 6

Corporate Debt Ratios and Inflation 
Purely financial intermediaries may perform further repackaging. Through term lending, for example, commercial banks transform longterm business debt into shorter-term deposits.

Now consider the effects of high and variable inflation rates on investors' demand for securities. If investors prefer short-term, or at least variable rate securities in such an environment, and if commercial banks no longer find maturity intermediation a viable activity, nonfinancial corporations will have to perform this function themselves. That is, they will repackage more of their assets in the form of short-term and floating rate debt instruments. Thus inflation, and in particular uncertain inflation, may affect not so much the debt-equity mix, but rather the kinds of debt instruments corporations must issue to satisfy the needs of investors. D. Federal Government Borrowing

Corporate financing behavior should also be influenced by the behavior of other sectors in the financial system. For example, the supply of federal government debt will condition investors' willingness to absorb the relatively low-risk fixed claims represented by corporate debt. While not often cited as a determinant of the corporate financing mix, government borrowing may thus exert an important influence on the financing activities of the corporate sector as a whole. 8

(FIG. 7 HERE)
Evidence in support of such a relationship is presented in Figure 7 , in which the ratio of federal government debt to that of all domestic nonfinancial sectors is graphed against the replacement value debt ratio for corporations. There appears to be a strong inverse relationship between the two series. In the early part of the century, when government debt was small, corporations satisfied investors' demands for safe, fixed claims 


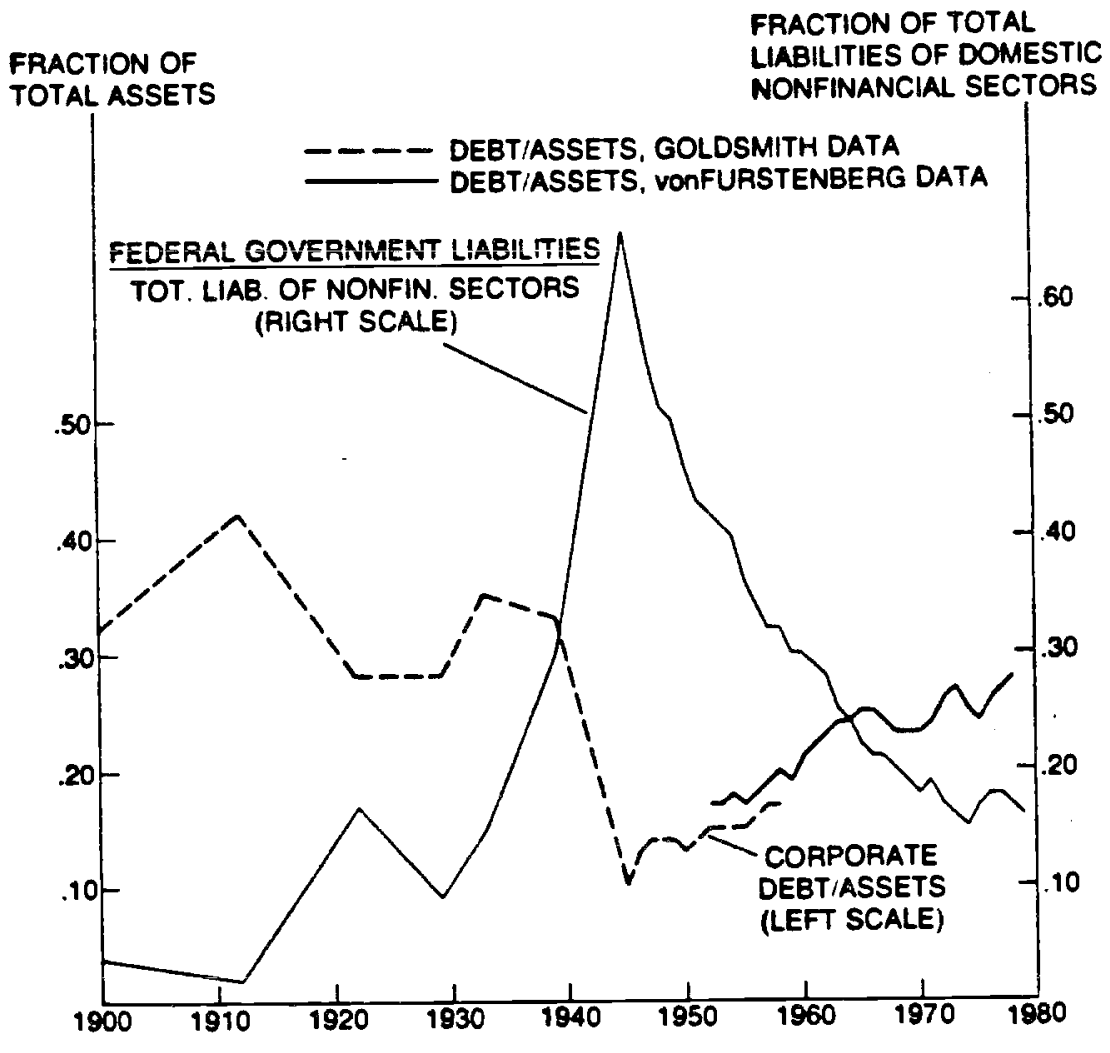

Figure 7

Corporate Debt Ratios

and Federal Government Borrowing 
by issuing large proportions of their own debt. Then, as federal borrowing swelled during the Depression years and World War II, corporate debt proportions fell drastically.

The inverse relationship is even more striking if we recall from Table 4 that corporations held large proportions of government securities in 1945. Not only was the amount of government debt curtailing corporate debt proportions, but, in effect, corporations were repackaging some portion of that government debt in the form of corporate equity.

Following Worid War II, the trend in the share of government debt has been primarily downward, while corporate debt ratios have simultaneously drifted upward. Moreover, many of the short-term swings in government debt share have been mirrored by opposite movements in corporate debt proportions.

When the evidence on determinants of corporate financing patterns is viewed as a whole, the influence of the federal government stands out sharply. Although their short-run impacts are more difficult to discern, it has been argued that perceived business risk, the tax system and inflation all appear to exert a broad influence on the financing of the corporate sector. All three factors are in turn heavily influenced by federal government activities. In addition, government regulations affect financial institutions' ability to diversify their portfolios, pay market interest rates, offer new customer services and hence to fully perform their intermediation function. Indirectly, then, such regulations influence the extent to which corporations must perform this function themselves. Finally, as indicated by Figure 7, the government's borrowing affects corporate financing behavior by altering relative supplies of securities in the capital markets and hence their relative prices. Apart from the ebb and flow of investment opportunities and internal funds, therefore, the activities of the federal government may be 
the major underlying determinant of corporate financing patterns. III. Conclusion

Overall, the analysis of this paper suggests that the financial condition of U.S. corporations is subject to a number of powerful corrective mechanisms. These mechanisms are unlikely to allow the business sector by itself to be the leader of an unchecked slide toward financial disaster.

First, there is some evidence that a rise in perceived business risk causes firms to moderate their reliance on debt financing. This tendency is hard to observe during short-run business cycle swings, but as business risk changes over prolonged periods it is more noticeable. It is certainly evident in the sharp cutback in debt proportions in the wake of the Great Depression, for example. It also seems likely that some of the moderation in debt financing in recent years has been motivated by perceptions of increased business risk.

Second, long-run balance sheet targets send strong danger signals when financing proportions get too far out of line. This is particularly apparent in the Flow of Funds data in Tables 2 and 3, as debt financing was curtailed after reaching historically high levels during 1969-73.

Moreover, it does not appear that these traditional balance sheet targets have been adjusted for inflationary distortions. The data in Table 3 suggest that, once corrections are made for changes in real indebtedness, corporate financial policies were quite conservative in recent years. This may stand as testimony to the difficulty of convincing lenders that traditional balance sheet ratios do not have the 
same meaning in inflationary periods. Indeed, U.S. corporations have severely curtailed dividend payments and have placed heavy reliance on internal funds since the mid 1970 s in an effort to reduce their dependence on external suppliers of funds.

Finally, the behavior of other sectors in the capital market, particularly the federal government, can act as an important check on corporate borrowing. Any one corporation is probably small enough that it need not worry about the effects of its own securities issues on the relative supplies of different types of instruments. The corporate sector as a whole, by contrast, must compete with the other sectors who are primarily issuers of debt. As the federal government in particular increases its borrowing, investors' appetite for corporate debt will be less strong and corporations may turn toward other financing sources, especially internal equity.

While these forces act as checks against excessive risk-taking, it should not be inferred that U.S. corporations face no financial problems whatsoever. In the presence of inflation and volatile interest rates, corporations have increasingly had to take on some of the intermediation functions that traditional financial institutions have no longer been able or willing to perform. This has led them to rely more heavily on short-term liabilities and has necessitated more frequent rolling over of their outstanding debt.

The outlook for inflation and economic stability, then, is one of the keys to future corporate financing patterns. These forces will determine whether corporations face the same sharp swings in internal funds availability that they experienced in the 1970s and early 1980 s. They will also influence the allocation of financial intermediation activity between corporations and financial institutions. 
A second major problem that business corporations face is the future course of government financing. To the extent that potential corporate borrowing is crowded out by the federal government, the corporate sector faces some potentially painful choices: it must cut dividends in order to increase internal funds, it must raise external equity, or it must cut back on capital spending.

In part, uncertainties about future corporate financing patterns reflect uncertainty over the future course of inflation, economic stability and government borrowing. It should also be clear, however, that a good part of any residual uncertainty stems from the fact that we still have much to learn about these patterns. The effects of business risk, taxes and inflation leave traces in the data, but these forces do not appear to be the whole story. Moreover, their effects are more subtle and more difficult to uncover than has commonly been thought.

At least two remaining issues require a better understanding. One of these is the behavior of equity issues. Why, for example, were corporations so much more willing to issue equity earlier in the century than they have been in the postwar years? Is this entirely a tax-related phenomenon or are other forces at work? A second important issue is the precise nature of the linkage between the borrowing activity of the federal government and the financing, dividend and investment policy of the corporate sector. 


\section{Footnotes}

1. This feeling is especially prevalent among members of the business press (see Bennett 1984; Business Week 1974, 1982; and Carson-Parker 1981 ) and analysts of the financial system (see Kaufman 1981, Mains 1980, Massaro 1977 and Moran 1984). Government officials have also expressed concern over corporate financing trends, particularly in the wake of the leveraged buyout boom (e.g. Shad 1984).

2. Perceived trends, of course, are always dependent on the observer's reference point. Miller (1963) examined the same data from 1926 through the mid-1950s and concluded, quite reasonably, that there had been no trend in corporate debt ratios over this period.

3. Gordon and Malkiel (1981) present evidence for the period 1973-78 suggesting that inclusion of lease and pension obligations would increase reported debt ratios by approximately one-third.

4. Some portion of bank loans should in fact be classified as longterm, but the actual fraction is impossible to estimate with any degree of confidence. There is no evidence of any trend toward increasingly long-term bank loans from, say, the mid-1960s onward. Moreover, the predominance of floating rate loans in recent years implies that even bank term loans have many of the characteristics of shortterm debt. 
5. See also Mitchell (1983) for an elaboration of the argument that, even if liquidity ratios have declined, the growth of bank loan commitments and the commercial paper market have increased corporations' ability to raise funds on short notice.

6. Other measures indicate an increase in business risk around this time as well. Wood (1981), for example, shows that the volatility of real interest rates increased sharply after 1972. Bodie, Kane and McDonald (1984) show that the real risk premium on long-term bonds suddenly jumped in 1979 .

7. Specifically, the debt incentive tax ratio is $\left(t_{c}-t_{p}\right) /\left(1-t_{p}\right)$, where $t_{c}$ is the corporate tax rate and $t_{p}$ is the lowest personal rate. In Miller's (1977) model this measures the net tax advantage per dollar of corporate debt when investors have tax rate $t_{p}$.

8. Exceptions include Friedman (1982) and Kaufman (1981). 


\section{References}

Bennett, Robert A. 1984. Risky Trend in Business Borrowing. New York Times, May 27.

Bodie, Zvi, Kane, Alex and McDonald, Robert. 1984. Why Haven't Nominal Rates Declined? Financial Analysts Journal 40 (March/Apri1): 16-27.

Business Week. 1974. The Debt Economy. Special Issue, October 12. 1982. Debt's New Dangers. June 26.

Carson-Parker, John. 1981. The Capital Cloud Over Smokestack America. February 23: 70-80.

Friedman, Benjamin M. 1982. Debt and Economic Activity in the United States. In Friedman, Benjamin, ed. The Changing Roles of Debt and Equity in Financing U.S. Capital Formation. Chicago: University of Chicago Press.

Goldsmith, Raymond W. 1958. Financial Intermediaries in the American Economy Since 1900. Princeton: Princeton University Press.

1982. The National Balance Sheet of the United

States, 1953-1980. Chicago: University of Chicago Press. 
, Lipsey, Richard E. and Mendelson, Morris. 1963

Studies in the National Balance Sheet of the United States. 2 Vols. Princeton: Princeton University Press.

Gordon, Roger H. and Malkiel, Burton G. 1981. Corporation Finance. In Aaron, H.J. and Pechman, J.A. eds. How Taxes Affect Economic Behavior. Washington D.C.: The Brookings Institution.

Holland, Daniel M. and Myers, Stewart C. 1979. Trends in Corporate Profitability and Capital Costs. In Lindsay, R., ed. The Nation's Capital Needs: Three Studies. New York: Committee for Economic Development.

Kaufman, Henry. 1981. National Policies and the Deteriorating Balance Sheets of American Corporations. Address to the Conference,-February 25. New York: Salomon Brothers.

Mains, N.E. 1980. Recent Corporate Financing Patterns. Federal Reserve Bulletin 66: 683-90.

Massaro, Vincent G. 1977. Corporate Capital Structures and Financing Patterns, 1977-80. New York: The Conference Board.

Miller, Merton H. 1963. The Corporation Income Tax and Corporate Financial Policies. In Commission on Money and Credit, Stabilization Policies. Englewood Cliffs, N.J.: Prentice-Hall. 
- 1977. Debt and Taxes. Journal of.

Finance $32: 261-75$.

Mitchell, Karlyn. 1983. Trends in Corporation Finance. Federal Reserve Bank of Kansas City Economic Review 68 (March): 3-15.

Moran, Miciael J. 1984. Recent Financing Activity of Nonfinancial Corporations. Federal Reserve Bulletin 70: 401-10.

Myers, Stewart C. 1984. The Capital Structure Puzzle. Journal of Finance 39:

Shad, John S.R. 1984. The Leveraging of America. Wall Street Journal. June 28 .

Taggart, Robert A. Jr. 1984. Secular Patterns in the Financing of U.S. Corporations. In Friedman, Benjamin M., ed. Corporate Capital Structures in the United States. Chicago: University of Chicago Press, in press.

Von Furstenberg, George M. 1977. Corporate Investment: Does Market Valuation Matter in the Aggregate? Brookings Papers on Economic Activity 2: $347-97$.

and Malkiel, Burton G. 1977. Financial Analysis in an Inflationary Environment. Journal of Finance 32: 575-88. 
Wood, John H. 1981 Interest Rates and Inflation. Economic Perspectives, Federal Reserve Bank of Chicago 5 (May/June): 3-12. 